\title{
在宅曣下障害患者の摂食に関する検討
}

西尾 正輝 新美 成二

要 約 : 在宅曣下障害患者 35 例を対象として攝食状況について調査し健常者群と比較し, 以 下の結果を得た。

1） 1 日の食事の回数に有意差は認められない.

2) 1 回の食事の所要時間は有意に長い.

3 ) 主食, 主菜・副菜では捸取頻度が有意に低下寸る品目が多いのに対して, デザート, 飲 物, 菓子では攝取頻度に差が認められない品目が多い.

4 ）摂取しやすい食品を選択する一方で喍好性の高い食品を選択している傾向にある.

5 ）食事に対する満足度は有意に低下する。

また嚥下障害群の $82.9 \%$ で病前と比較して体重の減少が認められた。

以上の結果に基づいて, 在宅䜩下障害患者に対するマネージメントプランについて検討を加 えた.

索引用語：摂食, 曣下障害, 統計的調査, ケア・システム

\section{Study on Diet in Dysphagic Patients at Home}

\section{Masaki Nishio, Seiji Niimi}

\begin{abstract}
A survey was conducted on the diets of 35 dysphagic patients staying at home in comparison with the diets of healthy subjects. The following results were obtained $: 1$ ) The number of meals per day in two groups was not significantly different ; 2) The duration of meals was significantly longer in the dysphagic group than in the control group ; 3) Although intake of many staple foods, main dishes, and secondary dishes was significantly lower in the dysphagic group than in the control group, there were no significant differences with respect to the intake of many desserts, beverages, and confectioneries between the groups ; 4) The dysphagic patients tended to consume foods that were easy to eat, and their favorite foods ; 5) The degree of satisfaction with dietary life was significantly lower in the dysphagic group than in the control group. In addition, body weight loss was noted in $82.9 \%$ in the dysphagic group, as compared with that before the onset of their diseases. Based on these findings, the management system for dysphagic patients staying at home was discussed.
\end{abstract}

Key words : diet, dysphagia, statistical investigation, care system 


\section{はじめに}

近年嬩下障害に対する関心の高まりとともに各医療 施設で除々に曣下障害食の考案・改善がなされ, 入院 患者に対する臨床栄養サービス・システムの有用性が 示されている ${ }^{1 \sim 4)}$.これに対して, 在宅嚥下障害患者に 対する支援システムの整備は大きく遅れている，原因 として，1）在宅曣下障害患者の摂食状況について調 查報告例が乏しく不明な点が多いために, ケアの必要 性が十分に認識されていないこと，2）ケア・システ ムが確立されていないために，医療の領域で蓄積され てきた知見が保健・福祉の領域で的確に反映されてい ないことが指摘されると思われる。 そこで今回, 在宅 曣下障害患者の提食状況について統計的調査を行い実 態を明確にするとともに，そのケア・システムについ て栄養学的側面ならびに QOL の側面から検討を加え たので報告する。

なお, 在宅嚥下障害患者の中には経管栄養を必要と する者が多数存在し，こうした患者に対するケア・シ ステムの検討も重要であろうが, 本研究においては栄 養摂取方法として経口摂取を選択している患者のみを 対象として検討した。

\section{方法}

\section{1. 調査対象者}

調查対象者は在宅曣下障害患者(以下，臙下障害群) 35 例ならびに比較対照群として在宅健常者 35 例（以 下, 健常者群) である (表 1 ). 年齢に両群間で統計学 的有意差は認められなかった。また両群の性別による 内訳数を対等にし, 與下障害男性群と健常者男性群, 曣下障害女性群と健常者女性群の年齢をそれぞれ比較 したところ，いずれも有意差は認められなかった。今 回の調査では在宅曣下障害患者の全般的傾向を把握す ることを目的としたため, 原因疾患, 発症後経過月数, 年齢に関して統制を加えなかった。その結果, 曣下障 害群の発症後経過月数は 0 ～180 力月（平均 44.5 力 月, SD 43.6）で，原因疾患は脳血管障害 11 例，筋萎 縮性側索硬化症 11 例, パーキンソン症候群 6 例, 脊髄 小脳変性症 3 例, 脳炎 1 例, 多発性硬化症 1 例, 重症
筋無力症 1 例，放射線ニューロパシー 1 例であった。

㫶下障害群ならびに健常者群の選択にあたっては, 地域による嗜好傾向の差異を排除するため千葉県東総 地区に在住の者に限定するとともに，家庭環境による 差異を回避するため独居ではなく調理および介護可能 な者と同居している者とした。健常者群は, 神経疾患 の既往がなく摂食・臙下機能上の問題を認めず，他の 疾患による食事制限を受けていない者とした。圖下障 害群は，以下の 4 条件を満たす者とした。

1 ）神経疾患に罹患後初めて㺞下障害が出現した者 (主に問診にて確認)。

2) X 線透視検査もしくは簡易評価法（問診，水飲 みテストなど) にて, 口腔準備相 (咀嚼困難など), 口 腔相（食塊の送り込み困難など）, 咽頭相（喉頭・気管 内流入もしくはむせなど）といった曣下の各相におけ る異常が確認可能であった者.

3 ）意識障害, 顕著な知的機能障害, 失語症など回 答に虚偽性が生じうる障害を合併していないこと（主 に Japan Coma Scale, Mini-Mental State，失語症ス クリーニング検査にて確認).

4 ) 消化器もしくは循環器系などの疾患により著し い食事制限を受けていないこと(問診にて確認).

また, 経口摂取がまったく不能である症例, 経管栄 養法を経口栄養法と併用している症例は対象から除い た.

\section{2. 調查方法}

1）攝食状況に関する調査

個別に面接して聞き取り調查を実施した。調査項目 は, (1) 1 日の食事の回数, (2) 1 回の食事の所要時間, (3)品目別攝取頻度, (4)食事に対する満足度, (5)体重の 変動の 5 項目である.(5)は曣下障害群にだけ実施した。

(3)の品目別捸取頻度は, 千葉県東総地区在住の健常 者が高頻度に摄取する品目を予備的に調査した上で先 行報告 ${ }^{1 \sim 3,5 ~ 9)}$ 参照として 82 品目から成る試作の調 查票を作成し, 11 名の在宅曣下障害患者に対してプリ テストを実施した ${ }^{10)}$.この結果にさらに検討を加え，主 食 7 品目, 主菜・副菜 37 品目, デザート 7 品目, 飲物 8 品目, 菓子 8 品目の 5 つのカテゴリーから構成され る総計 67 品目を調査の対象とした（表 2 ）。各品目ご

表 1 対象

\begin{tabular}{lccccccccc}
\hline & 例数 (人) & \multicolumn{3}{c}{ 年齢 (歳) } & & \multicolumn{3}{c}{ 性別 (人) } & \multicolumn{2}{c}{ 発症後経過月数 (月) } \\
\hline & & Mean & SD & Range & 男 & 女 & Mean & SD & Range \\
嬿下障害群 & 35 & 62.1 & 10.5 & $38 \sim 78$ & 23 & 12 & 44.5 & 43.6 & $0 \sim 180$ \\
健常者群 & 35 & 62.3 & 10.9 & $38 \sim 81$ & 23 & 12 & & & \\
\hline
\end{tabular}


表 2 品目別摂取頻度の調査に使用した品目リスト

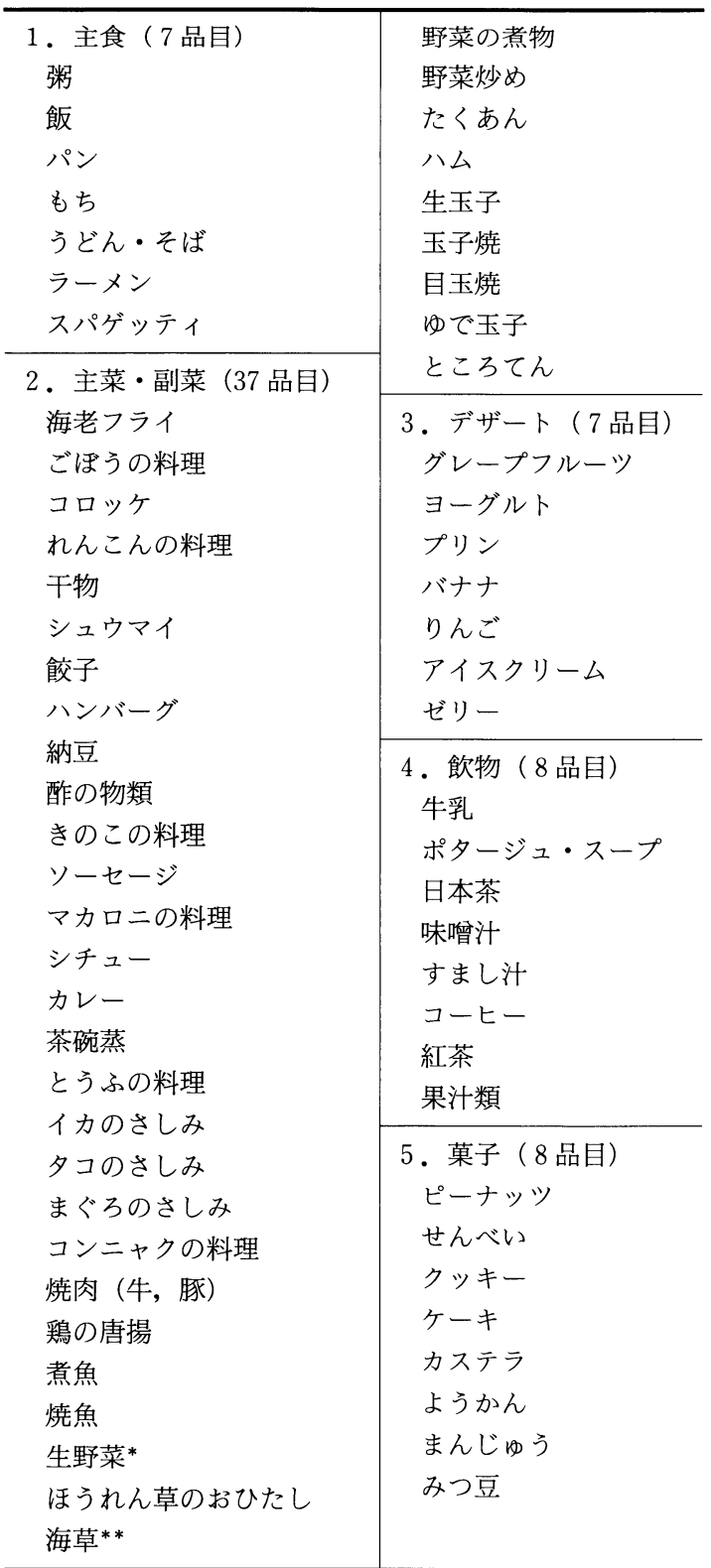

*：主にレタスとキャベツをさし，キュウリやトマトな どその他の野菜は含まない

**：千葉県東総地区特有の食品で, つるまた海草を煮て とかし寒天状に冷やし固めたもの

とに，「よく食べる」（2 点），「時々食べる」( 1 点), 「あまり食べない」（０点）の 3 分尺度で回答を求め, 解析に際して各尺度を数値化した。 なお, 飲食物の調 理形態に関連なく各品目の摂取頻度を求めた。

(4)の食事に対する満足度は食生活に対する主観的印 象を問い, 「満足」( 4 点), 「やや満足」( 3 点), 「どち
らでもない」( 2 点),「やや不満足」( 1 点),「不満足」 ( 0 点)の 5 分尺度で回答を求め, 各尺度を数值化した。

(5)体重の変動においては, 病前と比較した調査時 の体重について「増加している」( 2 点),「変わらない」 ( 1 点),「減少している」（0 点）のいずれかで回答を 求め, 各尺度を数值化した。

以上の調查は, 曣下障害群に対してはすべて 1 名の 言語聴覚士が外来診療時に実施した。健常者群に対し ては，14 名の言語聴覚士および栄養士が実施した。

統計学的解析にあたっては, スチューデントの $\mathrm{t}$ 検 定, マン・ホイットニーのU 検定, $\chi^{2}$ 検定, スピアマ ンの順位相関係数を用いた。

2 ) 䁵下機能の評価

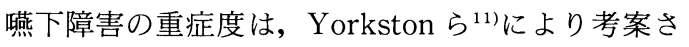
れたものを西尾 ${ }^{4}$ が一部改変した 6 段階評価尺度を用 いた (表 3 ).

\section{3 。調査期間}

1994 年 7 月から 1996 年 2 月までの 20 カ月間, 各症 例に対して 1 回実施した。

\section{結果}

\section{1 日の食事の回数}

1 日の食事の回数は, 健常者群では 3 回と回答した 者が際立って多く 33 例 (94.3\%), 2 回と 5 回がおの おの 1 例ずつ $(2.9 \%)$ であった。與下障害群でも 3 回 と回答した者が際立って多く 33 例 $(94.3 \%), 2$ 回と 1 回がおのおの 1 例ずつ (2.9\%)であった。1日の食 事の平均回数を算出すると, 健常者群では平均 3.0 回 (SD 0.4), 與下障害群では平均 2.9 回 (SD 0.4) で, 両群間に有意差は認められなかった。

\section{1 回の食事の所要時間}

1 回の食事の所要時間は健常者群では平均 21.1 分 (SD 8.3) で, 最短は 5 分, 最長は 45 分であった。曣 下障害群では平均 35.9 分 (SD 21.6) で, 最短は 10 分, 最長は 110 分であった。両群を比較すると, 嚥下障害 群は有意に長かった $(\mathrm{t}=3.76, \mathrm{p}<0.001) .40$ 分以上 所要する者は健常者群では 1 例 $(2.9 \%)$ のみであった が, 嚥下障害群では 11 例（31.43\%）もみられた。

\section{3. 品目別摄取頻度}

品目別摂取頻度の結果について, 以下にカテゴリー 別に示す.

\section{1）主食}

図 1 に主食 7 品目における両群の結果を示した. 図 中では, 與下障害群において平均得点の高い品目から 順に配列した。健常者群と比較して嚥下障害群は, 飯, うどん・そばなど 5 品目で有意に低值を示し, 粥では 
表 3 臙下障害の重症度尺度
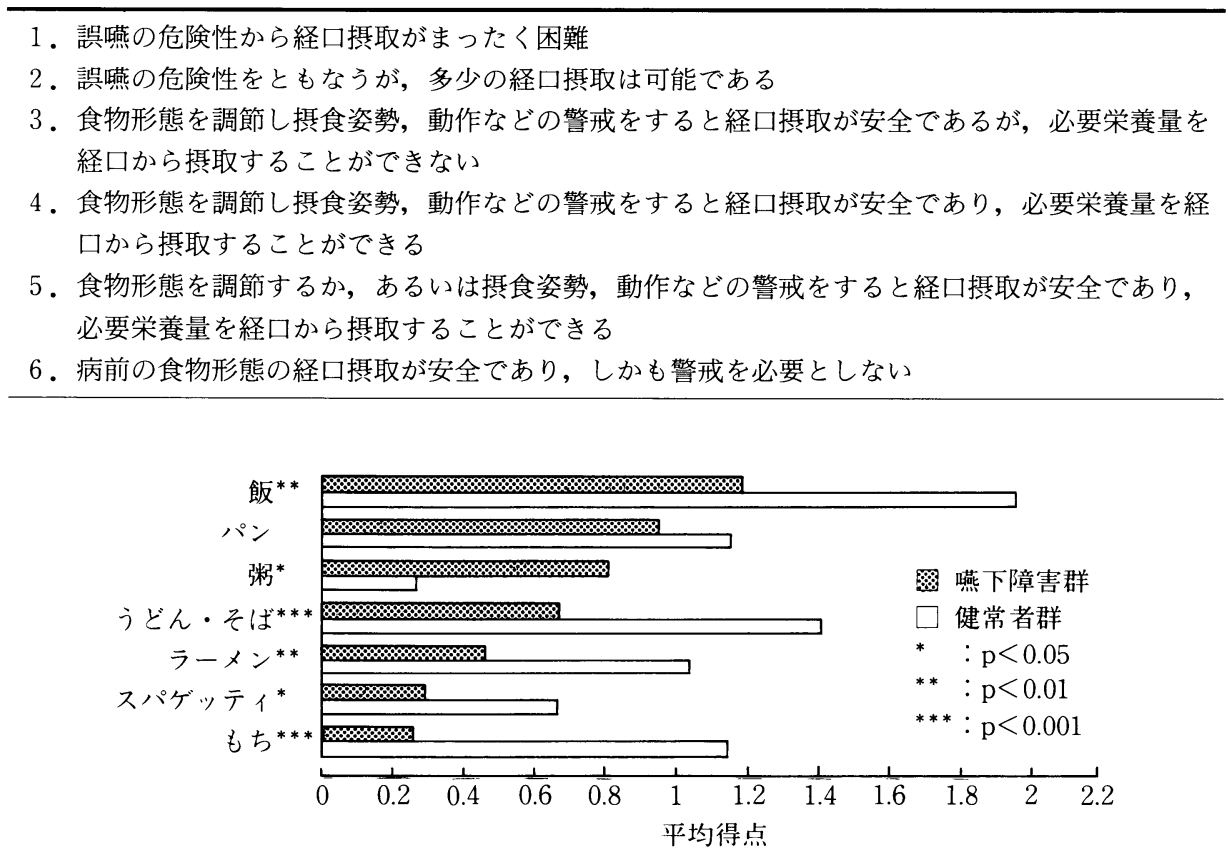

図 1 主食の摂取頻度

有意に高值を示した。パンでは有意差を認めなかった。

2 ) 主菜・副菜

図 2 に, 主菜・副菜 37 品目における両群の結果につ いて佐藤ら ${ }^{12)}$ の調査報告による咀嚼指数を参照として 比較的咀嚼が容易な品目群と困難な品目群と二分して 示した，嬩下障害群は，ほうれん草のおひたし，煮魚 など 24 品目で有意に低值を示した。これに対して，と うふの料理, 野菜の煮物など 13 品目では有意差を認め なかった。比較的咀嚼が容易な品目群と比較して, 咀 嚼が困難な品目群では有意に低值を示す品目がきわめ て多かった.

3 ）デザート

図 3 に, デザート 7 品目に扔ける両群の結果を示し た。曣下障害群は, りんごとグレープフルーツの 2 品 目でのみ有意に低值を示し, そのほかの 5 品目では有 意差を認めなかった。

4 ) 飲物

図 4 に, 飲物 8 品目における両群の結果を示した。 嶼下障害群はすまし汁でのみ有意に低值を示し, その ほかの 7 品目ではいずれも有意差を認めなかった。

5 ) 菓子

図 5 に, 菓子 8 品目における両群の結果を示した。 嚥下障害群はせんべいとピーナッツでのみ有意に低值 を示し,そのほかの 6 品目では有意差を認めなかった。

\section{4. 食事に対する満足度}

図 6 に，食事に対する満足度の調査結果を示した。 健常者群では「満足」と回答した者が際立って多く 27 例 $(77.1 \%)$ ，「やや満足」が 6 例 (17.1\%)，「どちら でもない」と「やや不満足」がおのおの 1 例ずつ $(2.9$ \%)で，「不満足」と回答した者はいなかった。これに 対して德下障害群では「満足」と回答した者が 4 例 (11.4\%)，「やや満足」が 13 例 (37.1\%)，「どちらで もない」が 4 例 (11.4\%)，「やや不満足」が 9 例 (25.7 $\%)$, 「不満足」が 5 例 (14.3\%) とばらつきがみられ, 両群間で有意差を認めた $\left(\chi^{2}=32.84, \mathrm{p}<0.001\right)$.

\section{5. 体重の変動}

病前と比較した体重の変動は䱌下障害群に対しての み実施したものであるが，「減少している」が 29 例 (82.9\%) と圧倒的に多く，「変わらない」が 5 例 (14.3 \%),「増加している」が 1 例 (2.9\%) であった（図 7 ). 脳血管障害例 (11 例) のみを抜粋して分析したところ, 「減少している」が 9 例 (81.8\%) と依然としてきわめ て多く，「変わらない」が 2 例 $(18.2 \%$ ）であった。

\section{6. 嚥下障害の重症度}

曣下障害群における曣下障害の重症度の内訳は，レ ベル 5 が 19 例で最も多く $(54.3 \%)$ ，レベル 4 が 9 例 (25.7\%)，レベル 3 が 4 例 $(11.4 \%)$ ，レベル 2 が 3 例 $(8.6 \%$ ) であった。レベル 6 および 1 に該当する者 
Vol. 39 No. 2, 1998. 4

a. 比較的そしゃくが容易な品目

とうふの料理

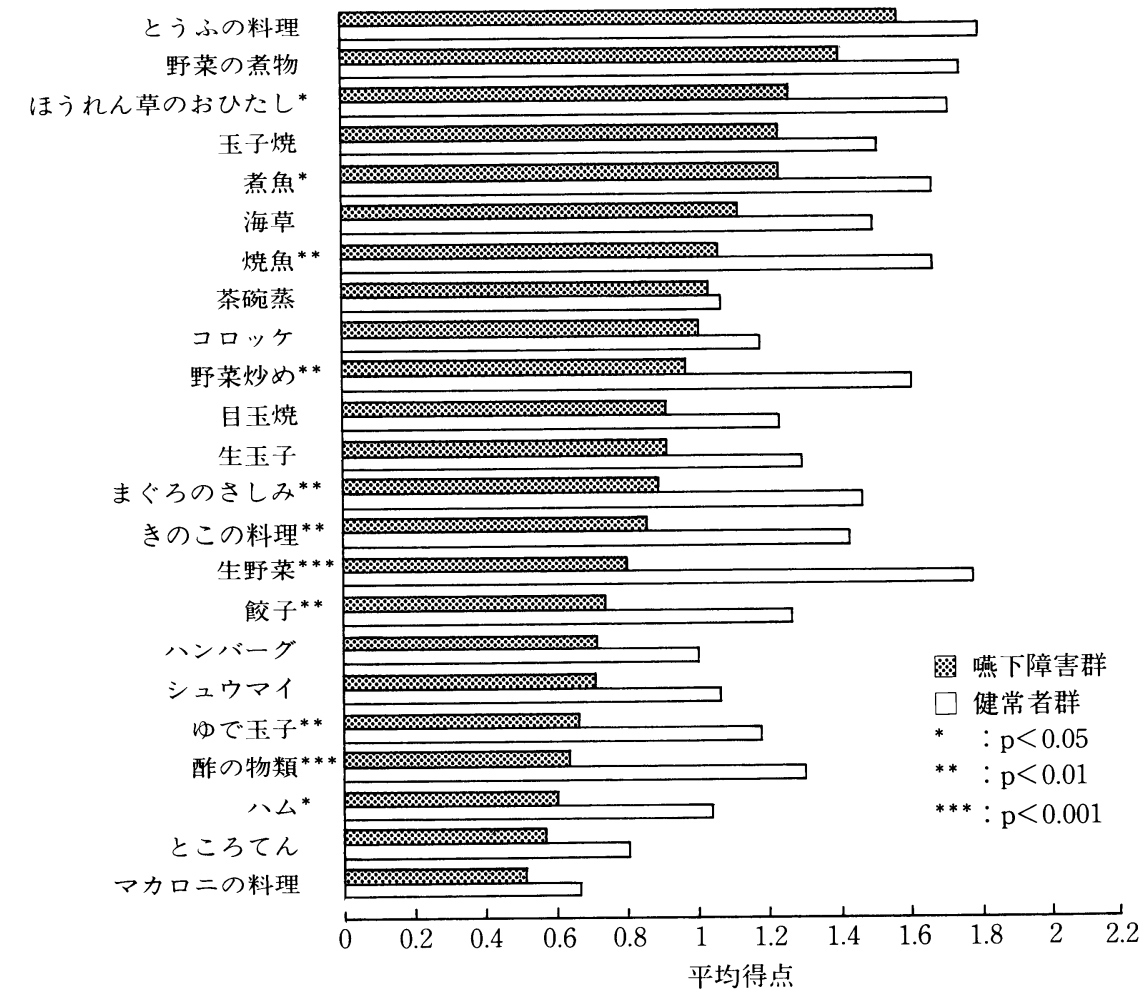

b. 比較的そしゃくが困難な品目

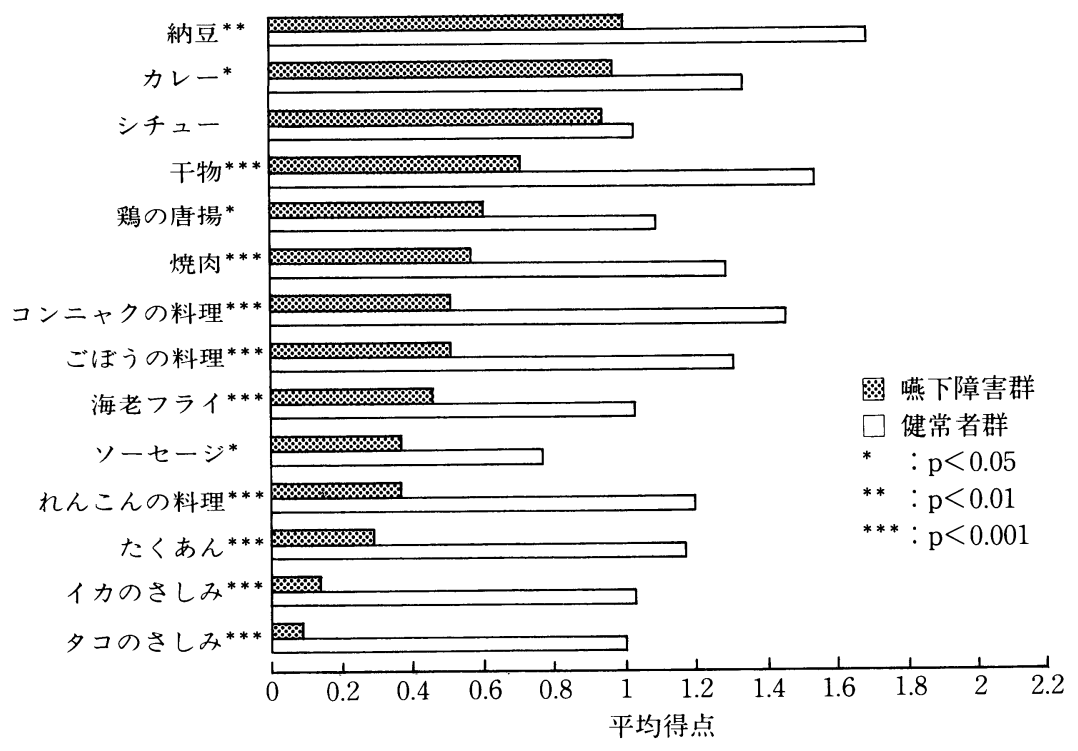

図 2 主菜・副菜の摂取頻度

は前述の通り今回の対象に含まれていない.

つぎに，曣下障害群における嬹下障害の重症度と品 目別摂取頻度を除く各調査項目との間のスピアマンの
順位相関係数を算出した. 1 日の食事の回数 $\left(\mathrm{r}_{\mathrm{s}}=\right.$ $0.65, \mathrm{P}<0.001)$, 食事に対する満足度 $\left(\mathrm{r}_{\mathrm{s}}=0.80, \mathrm{p}<\right.$ $0.001)$, 体重の変動 $\left(\mathrm{r}_{\mathrm{s}}=0.61, \mathrm{p}<0.001\right)$ とはともに 


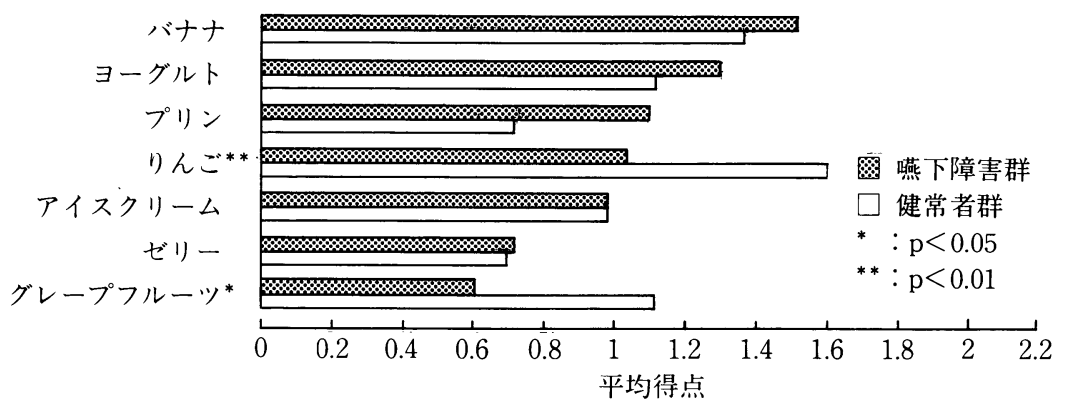

図 3 デザートの摂取頻度

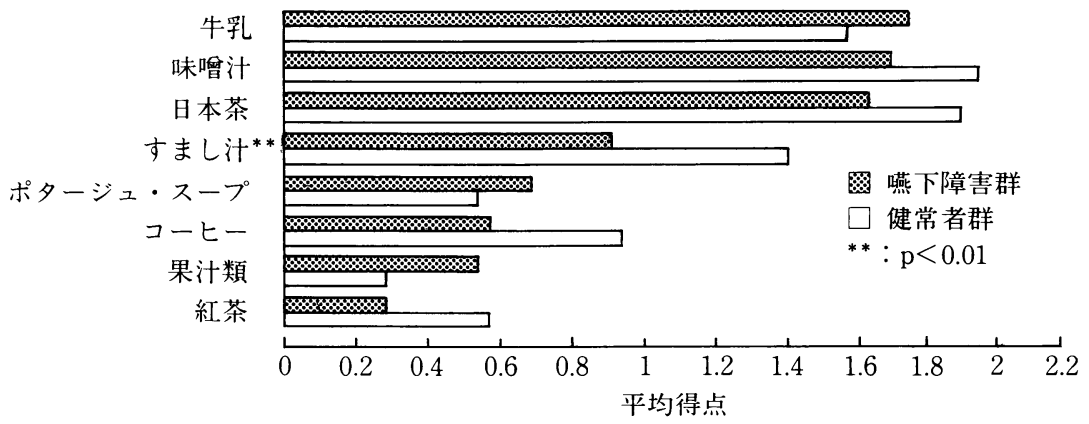

図4 飲物の攝取頻度

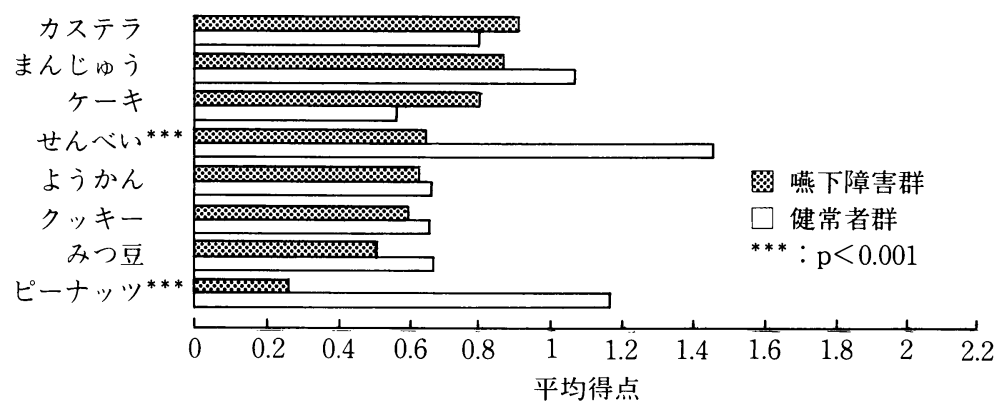

図 5 菓子の捸取頻度

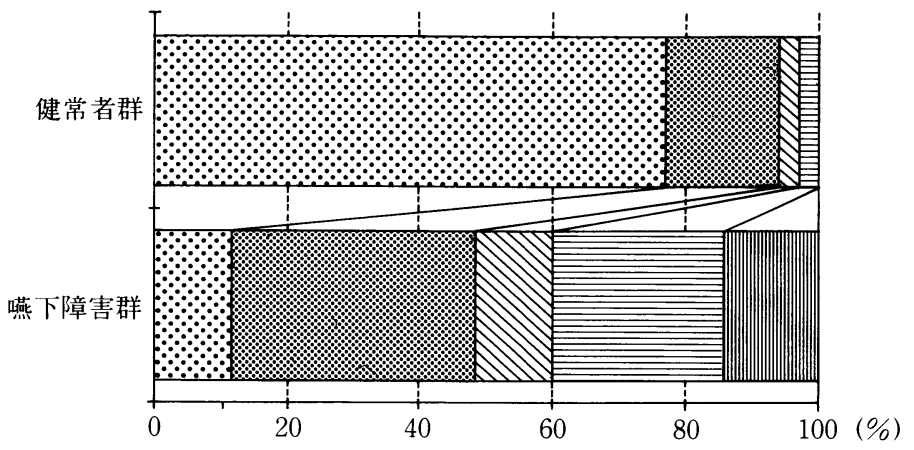

母満足 网やや満足 『どちらでもない 目やや不満足 四不満足 


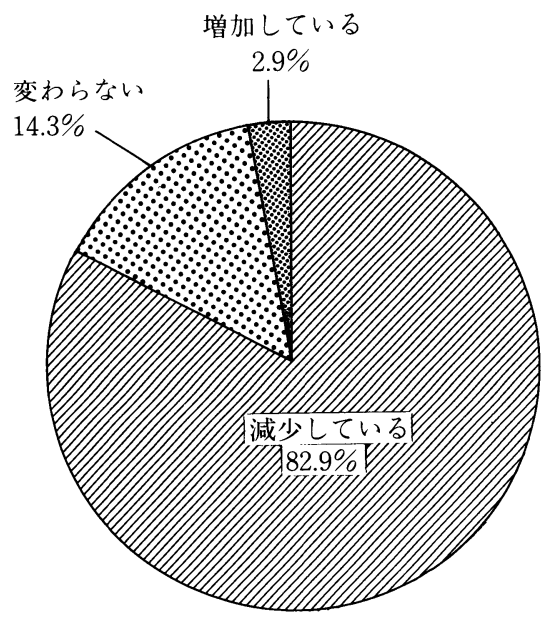

図 7 嬹下障害群における体重の変動

表 4 嬹下障害の重症度と各調査項目との 相関

\begin{tabular}{lc}
\hline \multicolumn{1}{c}{ 調査項目 } & \multicolumn{1}{c}{$\mathrm{r}_{\mathrm{s}}$} \\
\hline 1 日の食事の回数 & $0.65^{* * *}$ \\
1 回の食事の所要時間 & $-0.25 \mathrm{NS}$ \\
食事に対する満足度 & $0.80^{* * *}$ \\
体重の変動 & $0.61^{* * *}$ \\
\hline
\end{tabular}

***:0.001, NS : not significant

有意な相関を認めたが， 1 回の食事の所要時間とは有 意な相関を認めなかった（表 4 ）。

\section{考察}

\section{1. 在宅嚥下障害患者の摂食傾向について}

曣下障害患者に対する適切な飲食物として, 従来, 粘稠度が高いもの, 咀嚼が容易なもの, 適度に水分を 含んでいるものが指摘され，これに対して不適切な飲 食物として粘稠度が低いもの, 咀嚼が困難なもの, 乾 燥したもの，繊維成分を多く含むものが指摘されてき た ${ }^{1 \sim 8,10)}$. しかしこれらのほとんどは臨床的経験に基づ いて分類されてきたものである.

健常老人の嚥下の難易度については, 赤羽は9 が 358 例を対象としたアンケート調査から酢の物，焼いも， ゆで卵, 雑煮のもち, ウェハース, お茶, カステラ, 梅干し, ハンバーグ，もりそば，凍り豆腐，焼きのり， 食パンが特に飲み込みにくい品目であったと報告して いる.これらの食品目には乾燥したものが多く含まれ, この点で㫶下障害患者に対して不適切とされてきた前 述の一般的記載とある程度類似する．老人の一般的な
摂取傾向に関しては, 1993 年の国民栄養調査結果 ${ }^{13)} に$ よると年歯の上昇にともなって, いも, 豆, 果実, 野 菜類など植物性食品の捸取量が増大し, 油脂, 小麦, 肉などの摂取量は減少し, 米, きのこ, 魚介, 卵の変 動は乏しいと報告されている。岡崎 ${ }^{14)}$ の調査ではご飯 物, 漬物, 汁物, 煮物の順に高頻度に捸取されている と報告され，伝統的に国内で嗜好されてきた食物が攝

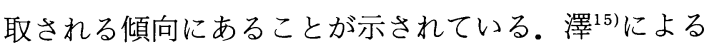
老人の攝食調査でも, 高頻度に摂取する食品と嗜好性 とが密接に関連していることが示されている.

品目別摂取頻度に関する今回の調査結果では, 嬹下 障害群は総計 67 品目の内 35 品目で有意に低值を示し た. 健常者群と比較して有意差を認めなかった食品目 もしくは健常者群よりも有意に高値を示した食品目に は, 一方ではポタージュ・スープやシチューなど粘稠 度が高いもの，とうふの料理やバナナなど咀嚼が容易 なもの, 粥や野菜の煮物など適度に水分を含んでいる ものといったように従来臨床経験的に曣下障害患者に 適切とされてきた品目が多く含まれていた，だが他方 では, 味噌汁や日本茶など粘稠度が低いもの, カステ ラやまんじゅうなど乾燥したものといったように不適 切とされてきた品目も含まれた。 これらの品目の多く は健常者群と㫶下障害群の両群で捸取頻度が高く, し たがって日本人にとって嗜好性の高い食品であると思 われる。もちやイ力など咀嚼が困難なもの, ごぼうの 料理やきのこの料理など繊維成分を多く含むものにつ いてはほとんど有意に低值を示したことから摂取が避 けられているとみられる。

以上から，在宅曣下障害患者は摂取しやすい食品を 選択する一方で嗜好性の高い食品を選択している傾向 にあることが明らかになったといえる。こうした結果 は，在宅嬹下障害患者の摂食指導にさいして特に危険 度が高いにもかかわらず嗜好性の高い食品に対して留 意する必要性を示唆するものといえよう。具体的な対 応策としては, 味噌汁やお茶など水状の食品に対して は増粘剤を加えて粘稠度を高め, 乾燥した食品に対し ては諸種のソースを加えるなどの工夫が適応となるで あろう。そのほか食物形態の調節方法を含めて, 在宅 嚥下障害患者に適つた食事に関する知識の普及が期待 される。そのためには嬹下障害に対して，1）退院時 の家族指導，2）退院後のフォローアップ，3）言語 聴覚士や管理栄養士などによる訪問指導を積極的に推 進するのみならず，保健婦やへルパーなど日頃から在 宅患者と接する機会の多いスタッフ間における知識と 関心のさらなる高まりが期待されよう. 


\section{2. 在宅蒸下障害患者の摂食に対するケア・システ ムについて}

1) 栄養学的側面に対して

厚生省は国民の健康作りのための食生活指針として 「多彩な食品で栄養のバランスを」として，1）1日に 30 食品を目標に，2）主食, 主菜・副菜をそろえて, と提唱している ${ }^{16)}$. しかし, 岡崎 ${ }^{14)}$ の高龄者世帯 203 世 帯を対象とした調査では 1 世帯 1 日平均 21.0 食品を 摂取していたと報告され，1 日 30 食品の摂取が困難で あると指摘されている．在宅嚥下障害患者の栄養状態 に関する報告例はきわめてそしいが，低栄養や脱水に より緊急入院を余儀なくされる症例が少なからず存在 することは臨床的に明らかである。

今回の結果ではほとんどの德下障害患者が健常者と 同様に 1 日 3 回食事を摄取していたが, 主食と主菜・ 副菜に関する多くの品目における摂取頻度の低下がめ だった.また $82.9 \%$ の患者で病前と比較して体重が減 少しているという深刻な結果が示され，体重の減少と 臙下障害の重症度との間に有意な相関を認めた。與下 機能障害が重症であるため経管栄養への変更が必要と 判断された患者も数例存在した.今回の対象の中には 筋萎縮性側索硬化症のように病変の進行にともない体 重の減少がやむをえない者も含まれていたため，脳血 管障害 11 例について検討したところ，81.8％（9 例） とやはり高率で体重の減少を認めた。䜩下障害にとも なう栄養学的側面の異常として, 低栄養と脱水がしば しば臨床経験的に指摘されてきた。今回の調査項目に は捸取されている栄養量と水分量を加えていないが, 摂取範囲の制限や体重減少といった結果から在宅曣下 障害患者におけるこうした危険性がある程度示唆され たといえる. 近年, 内外の各医療施設において除々に 臙下障害食の考案・改善がなされ, 臨床栄養サービス・ システムの有用性が相次いで示されている ${ }^{1 \sim 4,17,18)}$.こ れに対して在宅患者においては入院患者とは異なり地 域社会を基盤とした支援システムが求められるが，こ うしたシステムは国内ではなおも確立されていない.

以上から在宅䁵下障害患者に対して, 栄養学的に安 定した在宅生活を継続できるような社会的支援システ ムを構築することの必要性が示唆されよう．国内では 政府により 1989 年に策定された「高齢者保健福祉推進 十カ年戦略」により在宅ケアが重視され, 保健・医療・ 福祉が連携し合った支援システムが推進されている。 その具体的サービス内容としては, 訪問診療, 訪問看 護, 訪問リハビリテーション, ホームヘルプサービス, デイケア，入浴サービス，日常生活用具の給付などが 普及している，摂食面ではデイサービスの一環として
食事サービスが提供されているほか虚弱高齢者や障害 者に対する配食サービスの実施が各市町村で試みられ ており, 1992 年度からは毎日提供型の配食サービスに ついて国の補助制度が設けられた。さらに管理栄養士 による訪問栄養指導も普及しつつあり，1994 年には診 療報酬対象として認められた。

在宅嶼下障害患者に対しても，このような在宅ケア への関心の高まりとともに保健・医療・福祉に従事す る諸種の専門家がチームをなし噯下障害患者に対応し た食事サービスについて推進する必要があろう。従来 から嚥下障害の臨床においては医療スタッフによるチ ーム・アプローチの重要性が強調されており ${ }^{18 \sim 20)}$, こ こではさらにそれを拡張した地域社会における多機関 から構築される統合的なネットワークが基盤となろ う.

2) QOL (quality of life) に対して

黊下障害患者の満足度に関する報告例はきわめてそ しいが，筆者ら ${ }^{10}$ が入院患者を対象としたカテゴリー 別調査ではデザートと飲物で満足度が高いのに対して 主食と主菜・副菜では低下する傾向を認めた。

今回の結果でもデザート, 飲物, 菓子では搨取頻度 に有意差を認めた品目がめだって少なく，曣下障害患 者における食事の満足度という点でこれらの食品が重 要であると示唆された。しかし主食, 主菜・副菜では 有意差を認めた品目が多く,この結果嬩下障害が重症 化するほど摂取可能な品目の範囲が制限され食事全般 に対する満足度が低下したものと推察される。

近年心理的満足度は QOL を表す重要な指標である とする流れにあり ${ }^{21)}$, 食生活はその中でもとりわけ重 要な構成要素ともいわれる ${ }^{15,22)}$. 今回この満足度と嬩 下障害の重症度との間には高い相関を認め, すなわち 臙下障害が重症化するほど食生活の視点からとらえた QOL が低下する傾向にあることが示唆された。今回 「やや不満足」および「不満足」と回答した患者に追跡 調査を行いその理由を求めたところ, 病前から嗜好し ていた食品が食べられなくなったという意見が特にめ だった他, 食事に過剩に時間がかかり疲労する, 家族 と食卓をともにできない, 普通食とは違って舆下障害 患者用のミキサー・ペースト食は単調で味気ない，ま たこうした特殊な食事は離乳食を食べさせられている ようで情けないという意見がみられた。

したがって, 曣下障害に対しては単に適正栄養量の 確保のみにとどまることなく,QOL の側面から障害を とらえなおし, 経口摂取が可能な限り人間らしさを保 障するために「食生活の質」ともいうべき視点を含め た支援システムの必要性が示唆される. 在宅ケアの究 
極的目標がしばしば QOL の確保におかれる点から も ${ }^{23)}$ ，こうした側面からのケアを欠くことができない といえよう。こうした質的向上のためには, 前述のご とく社会的な在宅支援システムの充実に加えて患者の 家族全体の理解が高まり, 患者の嗜好性を尊重しつつ, 通常の形態では攝取困難な食品を攝取可能とするため の調理技術の向上が求められる.さらに嚥下障害食は 単調となりがちなため, 盛り付けや色彩, 食器, 季節 感のあるメニュー, 添え物の活用, 品目数の増加とい った外観と味に対する配慮が求められよう。このよう にして在宅嬿下障害患者が一家団欒の場としての意義 を有する食卓を家族とともに囲むことが QOL の向上 につながるものと思われる。

なお，今回は曣下障害患者を幅広く対象とし全体的 状況を把握することを目的としたが, 今後は原因疾患, 発症後経過月数, 年齢, 嶼下訓練や栄養指導経験の有 無，歯牙状況などの諸要因を統制した調査により検討 を深める必要があろう。

本研究においてご指導賜りました東京大学医学部耳鼻咽喉科 田山二朗先生, ならびにご協力頂きました旭中央病院栄養科遠藤 利江先生他栄養士の先生方に深謝申し上げます.

\section{文献}

1）窪田俊夫, 南波 勇, 野田裕子：脳卒中患者の麻 痺性嚥下障害とその治療計画. 診断と治療, 12 ： 2493-2497, 1986.

2）松崎政三，伊藤ひろみ：脳梗塞による嚥下困難者 の栄養管理. 臨床栄養, 79：160-163，1991.

3）安田恵子, 高橋静子, 遠藤利江, 他: 舆下障害の 食事. 旭中央医報, $15: 387-390,1993$.

4）西尾正輝, 星 研一, 桜井美和子, 他：嬩下障害 を合併した Dysarthria の臨床的マネージメント. 音声言語医学, 36：206-217, 1995.

5）伊藤裕之, 松本啓子：嚥下障害の食餌の検討一ア ンケートの結果より一.耳展, 31：329-333, 1988.

6）伊藤裕之：下咽頭の食物異物. 耳喉頭頸, $60 ： 677$ $-680,1988$.

7）伊藤裕之：曣下障害の食餌の検討. 日気食会報, $40: 357-360,1989$.

8）伊藤裕之：曣下障害のリハビリテーション. 耳喉 頭頸, 62：391-396, 1990.

9）赤羽ひろ, 手嶋登志子, 塩浦政男, 他：嚥下障害 をもつ高柃者のための “飲み込み易い食べ物”の 総合的検討. MOA Health Science Foundation
Research Reports, 1 : 177-191, 1993.

10）鎌形寿子, 遠藤利江, 西尾正輝, 他：臙下障害者 のアンケート調査を実施して。旭中央医報, 17 ： 102-104, 1995.

11) Yorkston, K. M., Honsiger, M. J., Mitsuda, P. M., et al. : The relationship between speech and swallowing disorders in head injured patients. J. Logemann (ed.), Journal of Head Trauma Rehabilitation, 4 : 1-16, 1989.

12）佐藤裕二, 石田栄作, 皆木省吾, 他: 総義歯装着 者の食品攝取状況. 補綴誌, $32: 774-779,1988$.

13）厚生省保健医療局健康増進栄養課監修: 国民栄責 の現状 (平成 3 年国民栄養調査成績), 第一出版, 61-85 頁, 1993.

14）岡崎光子：老人の食生活の実態と問題点.「老人の 食生活と栄養」, 医歯薬出版株式会社, 3-16 頁, 1991.

15）澤 純子：老人の食事, 嗜好, 調理.「老人の食生 活と栄養」, 医歯薬出版株式会社, 17-30 頁, 1991.

16）国民衛生の動向. 厚生の指標, 41 巻 9 号臨時増刊, 厚生統計協会, 88-102 頁, 1994.

17) Matthews, L. E. : Nutrition management in long term care. Journal of nutrition for the elderly, 8 : 59-64, 1988.

18) O'Gara, J. A. : Dietary adjustments and nutritional therapy during treatment for oral-pharyngeal dysphagia. Dysphagia, 4 : 209-212, 1990.

19) Logemann, J. A. : Evaluation and treatment of swallowing disorders. PRO-ED, 1983.

20) Martens, L., Cameron, T., Simonsen, M. : Effects of a multidisciplinary management program on neurologically impaired patients with dysphagia. Dysphagia, 5 : 147-151, 1990.

21）石原 治, 内藤佳津雄, 長島紀一：主観的尺度に 基づく心理的な側面を中心とした QOL 評価表作 成の試み。老年社会科学, $14: 43-51,1992$.

22）藤田美明, 大関知子：高齢者の栄養の問題点.「訪 問栄責指導ハンドブック」, 医歯薬出版株式会社, 11-18 頁, 1995.

23）村川浩一：在宅ケアの戦略的課題推進方策.「在宅 ケア最前線」, 医歯薬出版株式会社, 7-15 頁, 1994.

別刷請求先： $\mathbf{T} 113-8654$ 東京都文京区本郷 7-3-1

東京大学大学院医学系研究科音声 - 言語医学教室 西尾正輝 